\title{
Herding Behavior Detection: Bullish and Bearish Cases
}

\author{
Tomy Koputra ${ }^{1} \&$ Putu Anom Mahadwartha ${ }^{2, *}$
}

\author{
${ }^{1}$ University of Surabaya, Surabaya, Indonesia \\ ${ }^{2}$ University of Surabaya, Surabaya, Indonesia \\ *Corresponding author. Email: anom@staff.ubaya.ac.id
}

\begin{abstract}
This study aims to examine the presence of herding behavior on the Indonesian stock exchange (BEI), especially in the infrastructure, utilities, and transportation sectors. Daily data has been gathered for analysis from the 2013-2017 period, and this period was chosen to capture the extreme market movement, especially in bullish times. For this purpose, we use the herding behavior model by Christie and Huang (1995) to measure return dispersions from market return. The results fail to find any evidence of herding behavior in the infrastructure, utilities, and transportation sectors. Even in its sub-sectors, telecommunications are statistically significant in all market conditions where there is no herding behavior. These findings indicate that investors on BEI have heterogeneous beliefs and indicate that information is imparted efficiently to the investor to obviate their need to follow market consensus on their trading decisions.
\end{abstract}

Keywords: herding, behavior, investor, bullish, bearish.

\section{INTRODUCTION}

Behavioral finance explains several anomalies that cannot be explained through traditional financial models. One of them is herding behavior. The existence of herding behavior in financial markets is worthy of investigation for the reasons below. Many investors and financial managers pay attention to information that affects the stock price movement.

Herding occurs when someone decides to follow the market movements or other people's investment decisions rather than following self-confidence or essential information. This decision can make the movement of a stock does not move toward an efficient market. According to Bikhchandani \& Sharma (2001), the herding behavior is a situation when investors ignore the information they have and are more likely to follow the analyzed patterns that emerge in financial markets. Herding can be rational if a group that is followed has information that is only known to a handful of people or, based on Avery \& Zemsky (1998) when there is uncertainty about information owned by traders, investors behave as if rational in analyzing information.

Banerjee (1992) explains that herding behavior is the behavior of everyone doing what is done by most people even though publicly available information states that they must do the opposite. The authors find many terms about herding in several branches of science such as sociology, psychology, economics, neurology, and zoology. In economics and finance, patterns of herding behavior refer to the processes of economic agents that imitate each other in terms of their investment decisions - for example, the behavior of groups that carry out trading processes with the same pattern and time. (Nofsinger \& Sias 1999), investors who ignore their own investment decisions and prefer to follow other investors' trading behavior patterns because they are more dominant (Avery \& Zemsky 1998). Are the patterns of herding behavior rational? Some researchers reject the opinion that herding in some 
circumstances is a rational choice. Based on Demirer et al. (2010), the herding behavior pattern of investors is an alternative investment in the market. For example, investment managers will follow other investment managers in some circumstances to maintain their reputation or turnover, and junior analysts will follow another consensus rather than doing much further research due to worrying about their future in securities companies. In addition, the pattern of herding behavior can be said to be rational if the investor does not have a long-term horizon. For example, Froot et al. (1992) examine that if speculators have a short-term horizon, then they will be herding on the same information to learn what other investors know.

Several methods have been used to study herding. The first is done by analyzing herding, especially on institutional investors. This method was introduced by Lakonishok et al. (1992) and developed by Sias (2004). The second is done by checking herding through market consensus based on existing data in the capital market. This method was introduced by Christie \& Huang (1995), Chang et al. (2000), and Hwang \& Salmon (2004) and is widely used in financial literature. This latter method is easier to implement because it only calculates the rate of return of an investment based on available data, not based on daily trading activities.

The research results conducted by Christie and Huang (1995) show that herding behavior does not occur in stock exchanges in the United States when extreme market volatility occurs in any industry. This study is in line with Chang et al. (2000) that show herding behavior does not occur in stock exchanges in the United States but occurs in stock exchanges in Taiwan and South Korea in times of extreme market volatility. Shah et al. (2017) show the opposite results where herding behavior occurs in the transportation and multi-utility industries (gas and water) but not in other industries. Herding research is also conducted in Indonesia by Hana and Prasetiono (2017) applying a method developed by Chang et al. (2000) on the
Indonesian capital market. The results show a significant pattern of herding behavior. While other research by Pangesti and Koesrindartoto (2013) using the same method as Christie and Huang (1995) on nine industrial sectors on the IDX reveal that herding behavior pattern does not occur.

In this research, the herding process is measured based on return dispersion-based models or commonly known as CrossSectional Standard Deviation (CSSD). (Christie \& Huang 1995) and state-space models (Hwang \& Salmon 2004). While other studies by Chang et al. (2000) with the cross-sectional absolute deviations of returns (CSAD) method as a tool to measure the return distribution of a portfolio.

Herding behavior analysis method with CSSD has been done in previous studies and based on the background \& problem formulation, the hypotheses proposed for this study are as follows:

H1 : Stocks in the infrastructure, utilities, and transportation sectors show herding behavior in the JSX Index.

$\mathrm{H} 2$ : Stocks in the energy, transportation, toll road, telecommunications, and nonconstruction sub-sectors show herding behavior in the JSX Index.

\section{RESEARCH METHOD}

$$
\begin{aligned}
& \mathrm{rj}, \mathrm{t}=\text { stock return } \mathrm{j} \text { on } \mathrm{t} \\
& \mathrm{rt}=\text { cross-section average } \mathrm{n} \text { return on } \mathrm{t} \\
& \mathrm{n}=\text { stocks in portfolio on } \mathrm{t}
\end{aligned}
$$

There is an inverse difference between the rational asset pricing model and herding behavior, especially when the stock market is significantly corrected. The rational asset pricing model concludes that when the stock exchange is corrected, the level of return dispersion will be significant because of the sensitivity of each individual to their stock returns, while the herding model draws conclusions that are inversely proportional to the rational asset pricing model. To distinguish the two hypotheses above, the authors separate these different dispersion levels at 
the extreme tails level in the normal distribution curve at market returns where herding behavior usually occurs during extreme market movements both when the index rises or falls and to test whether it differs significantly from average dispersion using the linear regression model below:

$$
\operatorname{CSSD}_{t}=a+\beta_{1} D_{t}^{U}+\beta_{2} D_{t}^{L}+\varepsilon_{t}
$$

$D_{t}^{U}\left(D_{t}^{L}\right)$ is a dummy variable for market movement when rising or falling with market return movement at time t. DtL $=1$, if the return from the IDX stock index is in the lower tail dispersion and 0 vice versa. And $\mathrm{DtU}=1$, if the return from the IDX stock index is in its upper tail dispersion and 0 vice versa. The dummy variable in the regression equation above is used as an exploratory variable to distinguish extreme market periods from normal periods. An extreme market when market returns are in the upper and lower tails. The coefficient $\beta$ shows the relationship between the dispersion of return of an asset or portfolio and herding behavior patterns. If the herding behavior pattern is detected, then the dispersion will be small and vice versa; if the herding behavior pattern is not detected, the dispersion will increase. Coefficient values $\beta 1$ and $\beta 2$ show negative, meaning there is a herding behavior in the market while the rational asset pricing model shows positive results.

Secondary data was collected by downloading the required data, such as daily return data over the 2013-2017 period for stocks in the infrastructure, utilities, transportation sectors, and data returns from the CSPI over the 2013-2017 period. The 20132017 period was chosen as extreme bullish market patterns due to the IDX has increased to $44 \%$ on these periods.

\section{DISCUSSION}

To test patterns of herding behavior in the infrastructure and utilities sectors, CSSD is calculated daily during the $2013-2017$ period. This CSSD value is obtained from the daily return data of the shares of the infrastructure sector, the utilities chose was 35 shares. To find out the pattern of herding behavior in times of large market fluctuations, both bullish and bearish, a dummy regression model is used when the market goes up or down. Table 1 below shows the regression results that use $1-5 \%$ dummy both when the market goes up or down.

Table 1. Regression results to test herding behavior in the Infrastructure and Utilities sectors.

\begin{tabular}{lllll}
\hline Index & $\beta 1$ & $\mathrm{t}-$ Value & $\beta 2$ & $\mathrm{t}$-Value \\
\hline Du5/Dn5 & $0.003^{*}$ & 1.676 & $0.003^{* *}$ & 2.202 \\
Du4/Dn4 & 0.003 & 1.589 & $0.005^{* * *}$ & 2.706 \\
Du3/Dn3 & $0.004 * *$ & 2.111 & $0.005^{* *}$ & 2.272 \\
Du2/Dn2 & $0.006^{* *}$ & 2.267 & $0.005^{* *}$ & 2.171 \\
Du1/Dn1 & $0.008^{* *}$ & 2.273 & $0.006^{*}$ & 1.694 \\
\hline
\end{tabular}

The results in Table 1 show that the dispersion during extreme market movements is greater than during normal days. This also shows that in the infrastructure and the utilities sectors, in the 2013-2017 period when the JCI experienced a prolonged bullish trend, herding behavior does not occur because the positive results show that the value of CSSD will be even greater. These results are consistent with predictions of rational asset pricing and contradictions with predictive results from herding behavior patterns (Christie \& Huang 1995). This shows that stock investors in CSPI have heterogeneous beliefs in terms of investment decisions. This also shows that issuers in the infrastructure and utilities sectors have public information such as public exposures from issuers that are specific enough about investors or traders tend to trade issuers individually rather than following the direction of the consensus. (Henker et al. 2006).

The study also examines patterns of herding behavior in the telecommunications subsector (the biggest capitalization is in the infrastructure, utilities, and transportation 
sectors). Table 2 below shows the regression results that use $1-5 \%$ dummy both when the market goes up or down.

Table 2. Regression results to test herding behavior in the Telecommunications sub-sector

\begin{tabular}{lllll}
\hline Index & $\beta 1$ & $\mathrm{t}-$ Value & $\beta 2$ & $\mathrm{t}-$ Value \\
\hline Du5/Dn5 & $0.004^{* * *}$ & 2.929 & $0.006^{* * *}$ & 4.568 \\
Du4/Dn4 & $0.005^{* * *}$ & 3.167 & $0.006 * * *$ & 4.2 \\
Du3/Dn3 & $0.006^{* * *}$ & 3.417 & $0.007 * * *$ & 4.293 \\
Du2/Dn2 & $0.009^{* * *}$ & 4.058 & $0.007 * * *$ & 3.480 \\
Du1/Dn1 & $0.013^{* * *}$ & 4.411 & $0.009 * * *$ & 3.151 \\
\hline
\end{tabular}

The above results show that in the telecommunications sub-sector as the subsector with the highest capitalization in the sector, there is no significant positive herding behavior pattern either when the market is going up or down to the extreme. The above results are consistent with the lowest standard deviation of CSSD owned by the telecommunications sub-sector compared to other sub-sectors such as energy, transportation, non-building construction, toll roads, and infrastructure and utilities sectors. A lower standard deviation indicates that the dispersion value is more reliable for testing herding behavior patterns. This result is consistent with research conducted by Shah et al. (2017), showing no significant positive herding behavior patterns at $1 \%$. This shows that in the telecommunications sub-sector, investors in the IDX carry out trading or investment processes based on their own decisions without imitating any analysts' security forecasts either during a crisis or bullish euphoria. In addition, the results in the telecommunications sub-sector are also in accordance with the research of Ghalandari and Ghahremanpour (2013) that show confident investors expect their own information in terms of their investment decisions. This can also be caused by the telecommunications sector consisting of stocks with good fundamentals so that investors have different time horizons in terms of investment decisions.

Based on research that has been conducted on the detection of whether there is a pattern of herding behavior in the Indonesian stock market, especially in the infrastructure and utilities sectors in the 2013-207 period by using daily data returns, it is found that there is no significant positive pattern of herding behavior in these sectors except when upper tail $4 \%$ although not statistically significant. The most positive significant results in all market conditions (upper and lower tail 1$5 \%$ ) occur in the telecommunications subsector, where investors in this sub-sector are able to absorb information efficiently. Whereas the energy and transportation subsectors statistically produce insignificant results which means that this sub-sector cannot find a relationship between the dispersion of individual stocks with market returns. This shows that when the JCI was in a prolonged bullish period during the 20132017 period, investors in Indonesia have heterogeneous beliefs in terms of decisions for trading and investing in the stock exchange. This is consistent with Pangesti \& Koesrindartoto's (2013) research who conduct research on the IDX in nine sectors. With an increase in the number of investors, especially in 2017 by $16.4 \%$, it also produces investors who cannot be easily influenced by rumors in the market regarding their investment decisions, but they follow their personal investment decisions. This proves that the development of transactions through online trading makes investors more educated in absorbing information so that investment decisions become more rational and do not focus on consensus in terms of investment decisions.

\section{CONCLUSION}

This study has a limitation where it is only conducted on stocks in the infrastructure, utilities and energy, telecommunications, 
non-building construction, transportation, and toll road-building sub-sectors over the 2013-2017 period. In these periods, the market was experiencing prolonged bullish take daily returns from sectors and sub-sectors and daily market returns. Based on the study results, this study only focuses on its sector and macro index returns, whereas at the JCI, it seems that herding behavior patterns are more prevalent in micro sectors such as second and third liner stocks.

\section{REFERENCES}

Avery, C. \& Zemsky, P. 1998. Multidimensional uncertainty and herd behavior in financial markets. The American Economic Review 88(4): 724-748.

Banerjee, A.V. 1992. A Simple Model of Herd Behavior, The Quarterly Journal of Economics. 108(3): 797-817.

Bikhchandani, S. \& Sharma, S. 2001. Herd behavior in financial Markets. IMF Staff Papers. 47(3): 279-310

Chang, E.C., Cheng, J.W. \& Khorana, A. 2000. An examination of herd behavior in equity markets: an international perspective. Journal of Banking and Finance 24 (10): 1651-1679.

Christie, W.G. \& Huang, R.D. 1995. Following the pied piper: do individual returns herd around the market? Financial Analysts Journal 51(4): 31-37.

Demirer, R., Kutan, A.M. \& Chen, C.D. 2010. Do investors herd in emerging stock markets? Evidence from the Taiwanese market. Journal of Economic Behavior and Organization 76(2): 283295.

Froot, K.A., Scharfsten., D.S. \& Stein, J.C. 1992. Herd on the street: Informational inefficiencies in a market with short-term speculation. The Journal of Finance 47(4): 1461- 1484.

Hana Sendy, \& P. Prasetiono. 2017. Analisis Pendeteksian herding behaviour pada bursa saham emerging dan developed market Asia (Negara Indonesia, China, Singapura dan Jepang) tahun 2012-2016. Diponegoro Journal of Management 6(3): 243-253.

Henker, J., Henker, T., Mitsios, A., 2006. Do investors herd intraday in Australian equities? International Journal Management Finance 2(3): 196219.

Hwang, S. \& Salmon, M. 2004. Market stress and herding, Journal Empirical Finance 11(4): 585616.

Lakonishok, J., Shleifer, A. \& Vishny, R.W. 1992. The Impact of Institutional Trading on Stock Prices, Journal of Financial Economics 32(1):23-43.
Pangesti, A., \& Koesrindartoto, D. P. 2013. An Examination of Herding Behavior: An Empirical Study on Nine Sector Indices of Indonesian Stock Market. Proceedings Asian Academy of Applied Business. Bandung, $30^{\text {th }} \quad$ May- $1^{\text {st }}$ June 2013.Bandung: AAAB.

Shah, Mohay Ud Din, Attaullah Shah, \& Safi Ullah Khan. 2017. Herding behavior in the Pakistan stock exchange: Some new insights. Research in International Business and Finance 42 (December): $865-873$.

Sias, R.W. 2004. Institutional Herding, Review of Financial Studies 17(1): 165-206. 